\title{
JUURNAL_RU
}

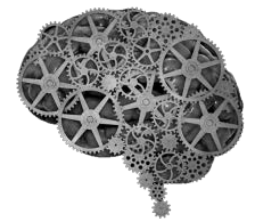

COMPANY GROUP "INTELLEKT"

Тимошкина Н.В. ФГБОУВО «СОГУ» Владикавказ, Россия

doi: 10.18411//j2016-9-1-12

idsp 000001: lj2016-18-1-12

\section{Возможности использования информационных технологий на уроках в начальной школе}

Особое внимание в новом Федеральном государственном образовательном стандарте (ФГОС) уделено знаниям и умениям в области информационных технологий, которые отражены в метапредметных результатах освоения основной образовательной программы начального общего образования.Согласно ФГОС метапредметные результаты освоения основной образовательной программы начального общего образования направлены на формирование умения использовать знаково-символические средства представления информации (схемы, графики, диаграммы, и др.); способствуют активному использованию средств ИКТ для решения задач различного уровня коммуникативных, познавательных; формируют навыки поиска информации (справочники, энциклопедии, сеть Интернет).

Наши учащиеся с помощью учителя должны осознать, что в будущей профессиональной деятельности от них потребуется колоссальный запас знаний не только по выбранной специальности, но и в области современных информационно-коммуникационных технологий. Большинство работодателей требуют от молодого специалиста не только минимальных компьютерных знаний, но и навыков владения информационно-коммуникационными технологиями, поэтому очень важно при обучении школьников максимально полно использовать разнообразные формы, методы и средства компьютерного обучения, что позволит им еще в начальной школе понять суть и принципы функционирования информационно-коммуникационных технологий. 
Уроки с использованием информационных технологий привлекательны не только детям, но и самому учителю. Они предоставляют возможность для саморазвития педагога и ученика. Новые компьютерные образовательные программы появляются достаточно регулярно, а значит растут и возможности их использования в учебном процессе. Изучение этапов подготовки урока с использованием ИКТ позволило выделить следующие:

I. Концептуальный этап заключается в обосновании необходимости использования средств ИКТ.

II. Технологический этап включает выбор методики (технологии) проведения занятий и проектирование основных видов деятельности учителя и учащихся, а также выбор вида взаимодействия учителя и ученика.

III. Операциональный этап предполагает осуществление поэтапного планирования урока, подготовку учебных материалов. Для каждого этапа определяются необходимо определить его цели с указанием конкретного результата, продолжительность этапа, форму организации деятельности учащихся с компьютерными средствами, деятельность преподавателя и функциональные обязанности на данном этапе, форму промежуточного контроля.

IV. Этап педагогической реализации заключается в установлении роли учителя на уроке с использованием компьютера, которая изменяется и педагог теперь не только источник знаний, но и управляющий процессом обучения, главной задачей учителя становится руководство познавательной деятельностью учащегося.

Исследование литературных источников и наш собственный опыт показывают, что ведение уроков со средствами информационных технологий позволяет повысить уровень первоначального усвоения нового материала до $75 \%$. У ребят появляется желание учиться, ходить в школу. Ученики с хорошим настроением учатся. Многие проявляют интерес к таким сложным наукам, как ботаника, зоология и др. Ребята, проявляя интерес и обладая пользовательскими умениями, вместе с родителями участвуют в8 различных викторинах и конкурсах, в том числе и виртуальных.

Таким образом, из всего выше написанного можно сделать следующие выводы:применение информационных технологий в образовательном процессе 
начальной школы позволяет дифференцировать процесс обучения младших школьников с учетом их индивидуальных особенностей; для творчески работающего учителя позволяет расширить спектр способов предъявления учебной информации; дает возможность осуществлять функциональное управление учебным процессом, является социально значимым и актуальным.

В своей деятельности нами использованы следующие формы работы с использованием компьютерных технологий:

- объяснение нового материала с опорой на мультимедийную презентацию;

- организация компьютерного тестирования;

- использование готовых электронных образовательных ресурсов;

- привлечение на различных этапах урока электронных энциклопедий;

- активная работа учителя и учащихся с интерактивной доской;

- заполнение электронного журнала.

Эффективностьобучения зависит отрациональнойорганизации работы учителя с использованием компьютера.Учебный процесс принесет больше пользы, если учитель сумеет правильно выбрать, определить необходимые формы работы с применением компьютерных технологий в каждом конкретном случае. 


\section{Литература:}

1. Тимошкина Н.В. Современные модели усвоения знаний с применением средств компьютерных технологий //Современный урок: новые подходы к организации. Чебоксары: ЦДИП «INet», 2014. - С. 77-79.

2. Тимошкина Н.В. Использование компьютерных технологий при изучении природы родного края //Начальная школа. -2009. -№ 3. -С. 92-95.

3. Тимошкина Н.В., Цаллагова А.Х., Тимофеева А.В Проектирование электронных учебных материалов как средство развития информационной компетентности будущих педагогов //Перспективные формы, методы и приемы организации учебно-воспитательного процесса: из опыта работы. Чебоксары: ЦДИП «INet», 2014. - C. 45-47. 